\title{
Testing of the Model of Creating a Specialized Tourist Product for Post- cOVID Time
}

\author{
Neven Šerića, Lidija Bagarićb ${ }^{b}$ Anđela Jakšić Stojanovićc, \\ Nevena Kekovićd
}

Specialized tourists offer in the post covid time is an important reason in choosing the destination to travel to. A new perception of this offer puts new challenges to those who design such offers. Most specialized offers are the result of entrepreneurial initiative and intuition. Authors have dealt with the creation of such offers as an important destination concurrent factor in their own cross-border cooperation. Based on their findings, they have developed a model of creating specialized tourism products for post covid time by linking core, additional, and expanded contents with brand creation and the marketing strategy. In this paper authors continue their research by testing that model through two platforms: desk research of the latest

\section{KEY WORDS}

$\sim$ Tourism

$\sim$ Model

$\sim$ Testing

$\sim$ Offer

$\sim$ COVID-19

a. University of Split, Faculty of Economics, Croatia

e-mail: nseric@efst.hr

b. University of Rijeka, Faculty of Tourism and Hospitality Management, Croatia e-mail: lidijab@fthm.hr

c. University of Donja Gorica, Faculty of Culture and Tourism, Montenegro

e-mail: andjela.jaksic@udg.edu.me

d. Superior, Ltd

e-mail: nevena.kekovic@gmail.com

doi: 10.7225/toms.v10.n02.021

This work is licensed under (cc) BY

Received on: 17.05.2021/Revised on: 22.09.2021/Accepted on: 17.10.2021/Published: 21.10 .2021 cognitions related to the repercussions of Covid-19 on tourist mind, and on a convenient sample of connoisseurs. The testing of the model is connected with one case study in which authors cooperate in practice. The findings have been tested through a survey on a sample of experts (representatives of travel agencies) related to their experiences in sales for 2020 and 2021. They have also found important changes in tourist perception of specialized tourist product. The findings offer the answers as to why the basic contents of the specialized tourist offer is no longer sufficient, as well as a way for developing additional and expanded contents, on which the brand and brand management activities in the post corona period should be primarily based, i.e. on what to base the marketing strategies in the post covid time.

\section{INTRODUCTION}

Before the outbreak of the covid 19 pandemic during the last decade there have been changes in the behaviour of tourists when choosing a destination, and changes in preferences towards tourist offers (Cooper, 2021; Baggio, 2020; Buhalis \& Sinarta, 2019; Buhalis et al., 2019; Richards, 2019; Nunkoo et. al, 2019; Boes et al., 2016). The authors have come to similar conclusions in their own research (Šerić et al., 2020C; Šerić \& Marušić, 2019; Šerić \& Batalić, 2018; Šerić et al., 2017). The findings of these studies warn us that the originality of the specialized tourist offer is no longer a sufficient prerequisite for competitiveness. Research conducted during the covid 19 pandemic period related to tourist behavior has also indicated drastic changes in tourist behaviour and consumption (Šerić et al., 2021; Cooper, 2021; Girish, 2020; Šerić et al.,, 2020A). It is evident that the competitiveness of a new specialized tourist product depends on how much it is adapted to the contents and perception of added value of the tourist 
expectations. The authors have analyzed the tourist behaviour on the coastal riviera of the Republic of Croatia and Montenegro during the main tourist season in 2020 (Šerić et al., 2021). They have exchanged data and information from their research with travel agencies and tourist offices in the Republic of Croatia and Montenegro. They have conducted a survey on appropriate samples of tourists who stayed on the coast of the Republic of Croatia and Montenegro during the main tourist season. The findings of the study warn that the covid-19 pandemic will have long-term repercussions on the behaviour of tourists in choosing a destination and specialized tourism products. According to the findings of the research, it can be concluded that the number of tourists for whom the basic tourist contents of a specific offer (destination, hotel) is no longer crucial in choosing a destination is significantly increasing. Due to the growing possibilities of selection within the category of similar basic contents (destinations, hotels), the decision on the final choice is increasingly made on the basis of additional and expanded contents of the offer. Given this fact, the authors define a research question RQ1: Given the growing importance of additional and expanded contents in choosing a tourist destination, should it be significantly implemented in the marketing strategy and brand of the tourist product?

So far the authors have practiced to develop the brand and marketing strategy of a specialized tourist product towards the basic content of the offer. The originality and differentiation of the specialized tourist product before the covid 19 pandemic were sufficient to attract the attention of tourists (Jafari \& Xiao, 2021; Ruhanen et al., 2019; Šerić \& Marušić, 2019; Šerić \& Batalić, 2018; Šerić et al., 2015). Recent research findings warn that additional and expanded contents of specialized tourist offer has stronger impact on its attractiveness and competitiveness (Šerić et al., 2021; Cooper, 2021; Baggio, 2020; Šerić et al., 2020A; Buhalis \& Sinarta, 2019). The authors believe that the additional and expanded contents of a specialized tourism product should have a greater significance in marketing strategy and brand as well. The starting point for the design and implementation of additional and expanded contents of a new specialized tourism product should be its basic feature. In this process the standards of related diversification of the tourist offer should be adhered to. For the purposes of testing the basic research question, the authors will use a specific specialized tourism product in the development of which they participate based on scientific cross-border cooperation between the Republic of Croatia and Montenegro - mini smart eco village Zelenika, Herceg Novi, Montenegro.

\section{LITERATURE REVIEW}

The adaptation of the specialized tourist offer to the targeted perception value of tourist implies relevant information about their habits during travel, and the way of their choosing a destination and specialized tourist offer (Jafari \& Xiao, 2021; McCabe, 2020; Gossline et al., 2020; Hall et al., 2020). Recent findings indicate changes in the perception of the value of specialized tourism products. Perception of value of additional and expanded contents significantly contributes to the final selection. Smart technological and environmental solutions in the offer are increasingly attracting the attention of tourists (Milano, et al., 2019; Ruhanen et al., 2019; Šerić et al., 2019). Ignoring these new insights can have negative consequences on destination competitiveness, receptive tourism entity occupancy and the sale of specialized tourism products (Cooper, 2021; Baggio, 2020; Buhalis \& Sinarta, 2019). Specialized tourist products are labour-intensive in case of a year-round offer and the engagement of specialized staff. Premium prices of such offers are based on the perception of added value (Buhalis \& Foerste, 2015). The originality and contents of the offer, as well as the resources engaged, contribute towards the perception of the added value of a specialized tourist product. The continuity of the development of specialized tourist products encourages the creation of new jobs, self-employment, and income growth of the local population of the receptive destination (Prorok, 2019). Recent research related to the effects of the covid-19 pandemic on the tourism economy indicates that specialized tourism products are more resilient than seasonal tourism products (Girish, 2020; Hall et al., 2020). Because of that fact, this issue should be given special importance.

More serious changes in the behaviour and consumption of tourists began to occur even before the outbreak of the covid 19 pandemic (WTTC, 2020). New insights should be accepted as a basis for managing the tourist offer. The competitiveness of a new specialized tourism product significantly depends upon the perceived value of the target tourism clientele (Wen et al., 2021; Zhang et al., 2021; WTTC, 2020; UNWTO, 2020). If, in addition to the basic contents, additional and expanded contents becomes evident, the tourist gets an impression of an even greater value of the offer (Šerić et al., 2021). Findings from recent research indicate that tourists rely less and less on previous experiences when choosing a destination and tourist facilities. Preference in choosing a destination and tourist contents is given to the offer that they rate as more meaningful and valuable (Prideaux et al., 2020; Hall et al., 2020; Šerić et al., 2020A; Jakšić Stojanović et al., 2019A and 2019B).

Specialized tourism products significantly contribute to the competitiveness of the destination and the wider tourist zone within which they are offered (Jafari \& Xiao 2021; Buhalis \& Foerste, 2015). Findings from recent research indicate that existing specialized tourism products need to be upgraded with additional contents in order to maintain their attractiveness. The attractiveness of specialized tourist content significantly contributes to its competitiveness (Šerić et al., 2020A). In the post- 
covid period, due to the further intensification of competition between receptive tourist countries and destinations, new insights related to the development and management of specialized tourist products have, in addition to application and scientific and wider social significance, opened new possibilities. New findings related to this could have important repercussions on the employment of the local population in tourism and the maintenance of the percentage of tourism income in GDP (UN 2020; Prorok et al., 2019). The development and management of specialized tourism products during recent years have become the subject of scientific consideration (Richards, 2019; Buhalis \& Foerste, 2015). The expectations of tourist demand are rapidly changing (Gossling et al., 2020). The steady growth of competition and the recession that will follow the end of the covid-19 pandemic impose the need for new research on this issue (Prideaux et al., 2020).

\section{BASIC, ADDITIONAL, AND EXTENDED CONTENTS OF THE SPECIALIZED TOURIST PRODUCT}

In the overall structure of the global tourist offer, specialized tourist products have shown a high growth rate over the last two decades. This segment of the tourist offer has increasingly significant repercussions on the growth of national tourism economies (Prorok et al., 2019). Specialized tourist products today represent one of the most dynamic and fastest growing categories of tourist offer. In addition to intensive growth, they are also characterized by encouraging tourists to travel throughout the year, which is why they are an important catalyst for extending the tourist season (Buhalis, Park, 2021). In many receptive tourist countries, specialized tourist products are an important component of the competitiveness of the national offer and an important development factor of the tourist economy (Buhalis, Sinarta, 2019). There are many challenges and dilemmas in relation to the development of specialized tourism products.

Atypical and unusual tourist facilities, adapted to the target tourist segments, are classified as specialized tourist products (Jafari \& Xiao, 2021; Šerić et al., 2020A). The creativity of the contents of the specialized tourist offer contributes towards its attractiveness (Jakšić Stojanović \& Šerić, 2018). With its total contents, the specialized tourist product combines different tourist needs - adventure, health, gastronomic, cultural, and others (Richards, 2019). Depending on the resources upon which each specialized tourist product is based, there are specific contents complexities. A more complex content enables more pronounced differentiation and greater attractiveness (Jakšić Stojanović et al., 2019A). The more pronounced differentiation of the specialized tourist product is a prerequisite for a higher premium price supplement (Šerić et al., 2020A). In terms of contents, it is possible to consider the basic, expected, additional, and extended contents within the specialized tourist product (Šerić et al., 2020A). The expected content is related to the preliminary impressions of the offer of the targeted tourist clientele, and it is not in the focus of this research. The basic content represents the idea and context of the offer and the marketing story about it. This content is the foundation of its recognizability. Additional content contributes to the attractiveness and allows modifications of the offer during the life cycle of a specialized tourism product. The expanded content represents the potential to attract different tourist segments. The elements of additional and expanded content of a specialized tourist product in practice are developed in the phase of its maturity (high demand) in order to maintain the relevant interest of demand for as long as possible. The perception of a specialized tourist product among tourists changes in accordance with the structure of the basic, additional, and expanded contents (Šerić et al., 2021; Jakšić Stojanović et al., 2019A; Jakšić Stojanović et al., 2019B). Based on this fact, the authors consider that in the new, post covid time, it would be recommended to implement all the components of the contents in its marketing strategy and brand. The differentiation and breadth of content characteristics of a specialized tourism product makes it practical for branding and developing a customized marketing strategy.

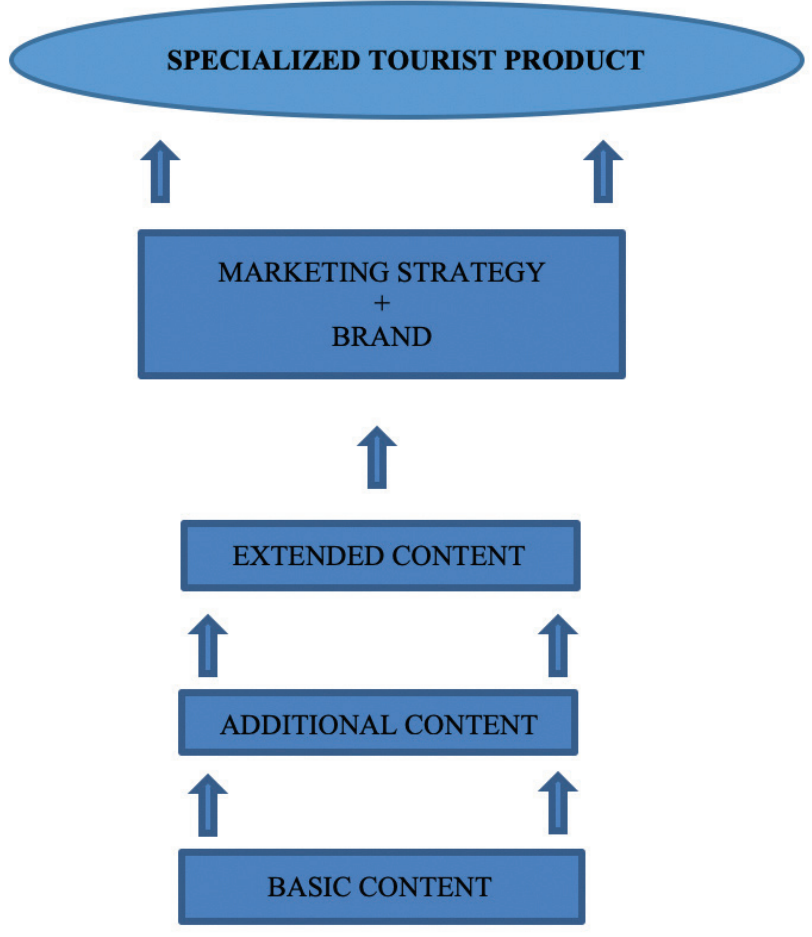

Figure 1.

Recommended model for the development of a new specialized tourism product for post covid time. 
The global supply of specialized tourism products is dynamic and continuously growing (Prorok et al., 2019). Acquiring the competitiveness of such tourist facilities depends on their market visibility. In order to increase market visibility and attractiveness of such tourist content, the authors are of the opinion that in addition to the basic content, special importance should be given to additional and expanded content, both in the development process and in the brand and marketing strategy, as shown in Figure 1.

\section{THE RESEARCH}

The research has been conducted on the example of a specialized family accommodation facility - mini smart eco village. The receptive subject is located in the Montenegro, Zelenika, near Herceg Novi, situated along the coast, below the Adriatic highway. The authors are collaborating on the project development based on cross-border collaboration. The basic content of the offer of the receptive subject is designed in accordance with the previous practice of the author in the development of new specialized tourist products (Šerić et al., 2020A). Additional and expanded content of the offer was developed using SWOT, TOWS, Pestec, Mof and Recoil analysis. This methodology has been selected in order to gain relevant insights into the content possibilities of the offer based on detailed findings of internal and external analysis. Given the specific, pivotal period of the global pandemic and the expected recession that has followed, a multidisciplinary approach was used, and experts from practice (representatives of travel agencies) were consulted in the implementation of the selected methodology and the findings of a survey of authors conducted during 2020 were taken into account (Šerić et al.,2021). The receptive subject has relevant transport infrastructure by road and air (two airports nearby and a regional road). The tourist zone in which it is located is currently frequented by tourists from the surrounding countries and tourists from Russia (by planes). In recent years, two luxury hotels, several high-category catering restaurants and several smaller marinas have been built around the area. Individual promotion of these new tourist entities contributes towards a strengthening the global visibility of the whole tourist zone, which is a prerequisite for attracting tourists from new emitting markets (Jakšić Stojanović \& Šerić, 2019; Jakšić
Stojanović et al., 2019A; Jakšić Stojanović et al., 2019C; Prorok et al., 2019; Melović et al., 2018; Luković \& Šerić, 2009; Šerić \& Luković, 2007). These facts and the possibility of diversification of a new, specialized receptive tourism entity, have prompted the idea of devising a concept that would attract smaller tourist groups from different emitting markets throughout the year. In accordance with this goal, basic, additional, and expanded contents have been designed. The idea has been developed on the standards of glamping tourism. Nine (9) small villas are built and equipped in accordance with high environmental standards (building and equipment). Waste selection within the complex has been planned, as well as recycling outside the village (prefabricated recycling yard). Smart technological solutions intended for guests contribute to the high quality and comfort of living with a variety of contents and equipment. The implemented technological solutions are based on high environmental standards. Some have already been confirmed in the authors' earlier tourism projects (Jakšić Stojanović \& Šerić, 2020; Jakšić Stojanović et al., 2019; Jakšić Stojanović et al., 2019B; Jakšić Stojanović \& Šerić, 2018A; Šerić et al., 2002). The targeted tourist segments are organized groups of employees (from smaller companies) who will stay here for trainings and team building. During the afternoon and evening, the hosts will organize various additional and extended activities (educational, gastronomic, sports, spiritual, health, entertainment, and others) within the complex. User smart solutions have also been implemented: self check in and self check out, smart TV communication platform, tablet management of basic, additional, and extended content of the offer, smart management of the interior atmosphere (light, music, multimedia), offer of special equipment and devices (Alexa, wireless chargers, additional mobile devices equipped with a local SIM card, etc.), concierge video chat (for communication with the reception). New technologies of sound insulation of buildings have been implemented, and the use of energy from renewable sources (sun and wind) has been ensured. Accommodation units are equipped with the highest energy efficiency equipment ECO certified. Energy-saving connections to the water supply network have been installed, and the ecological disposal of hygienic wastewater and its use for watering plantations has been ensured. 
Table 1.

SWOT analysis.

\section{STRENGHTS}

1)Innovative specialized accommodation offer;

2)Uniqueness of the offer in the tourist zone;

3)Location availability and traffic infrastructure;

4)Attractiveness of the location (proximity to the sea, road access,

infrastructure, preserved landscape);

5)Landscape recognizability of the tourist zone;

6)Preserved culture and tradition of the tourist zone;

7)Archaeological and historical heritage of the tourist zone;

8)Favorable microclimatic conditions (average 200 sunny days per year);

9)Experience of investors in construction and installation;

10)Experience in tourism and catering business of the subject;

11)Entrepreneurial experience and initiative of the entity for new projects;

12)Own construction land with enough space for additional facilities;

13)Good financial liquidity and creditworthiness of the entity;

14)Availability of bank capital;

15)Relevant network of partners and outsourcing associates;

16)Experienced management;

17)Economic technologies - lower costs of electricity, water supply and waste disposal;

18)Good image of the subject in the local community;

19)Production of organic food in the tourist zone.

\section{OPPORTUNITIES}

1)Post covid time - restart of tourism;

2)Aspiration of tourists for socialization after months of isolation;

3)The need for re-socialization of employees in companies after the covid pandemic;

4)Existing tourist contacts in the emitting market of Scandinavia and the Russian Federation and opening of new emitting markets;

5)Connecting with professional national associations of target emitting tourist markets;

6)Attracting new market segments;

7)Preferences of tourists for accommodation in smaller receptive facilities in post covid time;

8)Cooperation with maritime concessionaires and supply entities in the area;

9)Popularity of the concept of sustainable ecological tourist offer;

10)Trend of implementation of digital platforms in the tourist offer;

11)Possibility of obtaining a concession for a wider forest belt in the area;

12)Proximity to groomed hiking trails and cooperation with the mountaineering association;

13)Lower prices of construction and execution of the project in its own direction;

14)Positioning in the optimal niche (target tourism segment - organized groups of employees of small companies for education and team building);

15)Attractiveness of location, content and offer - the possibility of attracting different tourist segments;

16)Possibility to organize own guest transfers;

17)Availability before EU accession funds for financing such projects.

\section{WEAKNESSES}

1)Lack of own financial resources for project implementation, required credit indebtedness;

2)Limited accommodation capacity (9 units with 2 - 4

beds);

3)Lack of educated and experienced staff for animation

and maintenance of IT applications;

4)Lower solarization of the central open space with the pool due to the height of the whole buildings;

5)Some tourism segments do not accept the digital concept of communication during their stay;

6)The predominant tourist population in the tourist zone (countries of the region) undermines the impression of exclusivity;

7)Higher transportation costs (for building materials and equipment) due to the geographical position of the location;

8)Distance of the location from the highway crossroads; 9)Fragmentation of the offer of content in the nearby tourist zone;

10)Modest promotion and poor visibility of the tourist zone on the global tourist market.

\section{THREATS}

1)Prolongation of the covid pandemic;

2)Problems in the purchase of technologically specific equipment;

3)Non-recognition of the added value of the offer (eco and smart standards);

4)Non-recognition of the category of accommodation by the relevant Ministry - inadequate categorization;

5)Seasonality of the tourist visit in the area of the tourist zone;

6)Reducing the attractiveness of the wider environment (tourist zone) due to uncontrolled construction;

7)Employment of local staff in the surrounding countries (seasonal);

8)Financial and other liabilities of the entity in several developing projects;

9)Slow return on investment;

10)Higher cost of communal equipment if the target category of accommodation is not obtained according to the assessment of the relevant Ministry;

11)Increase in interest on other people's funds:

12)Complexity of applying for funds before the accession funds of the European Union;

13)Endangering the landscape and the purity of the sea by the growth of tourist construction in the tourist zone; 14)Emigration of educated young people from the area of the tourist zone (promising tourist staff). 


\section{STRENGHTS+THREATS}

1)Restart of tourism, innovative offer of specialized accommodation, problems in the purchase of technologically specific equipment, prolongation of the covid pandemic;

2)Aspiration of tourists for socialization and accommodation in smaller receptive facilities, the need for re-socialization of employees in companies, attracting new tourism segments, global visibility of promoting sustainable environmental tourism offer, non-recognition of the added value of the offer;

3)Attractiveness of the tourist zone, reducing the attractiveness of the tourist zone due to uncontrolled new construction, threats to the landscape and the sea;

4)Traffic accessibility and attractions of the tourist zone, seasonality of the tourist visit;

5)Available insorcing and outsourcing resources, employment of local staff in the surrounding countries, emigration of educated young people;

6)Good financial liquidity of investors, own experience in construction, availability of bank capital and European union funds, financial obligations of investors in other projects, rising interest rates on other people's funds, complexity of applying for European union funds, slow return on investment;

7)Good image and business networking of investors, problems in the procurement and financing of technologically specific equipment, inadequate categorization due to non-recognition of the category of accommodation by the relevant Ministry - higher costs of utility equipment;

8)Promotion of the year-round innovative offer in various emitting markets where tourist offers based on eco-smart contents are preferred, promotional prices in the off-season, extension of the covid pandemic.

\section{WEAKNESSES+THREATS}

1)Lack of own financial resources to complete the project due to commitments on other projects, problems in the procurement of technologically specific equipment, prolongation of the covid pandemic, delay with the commercialization of the project;

2)Distance of the location from the highway crossroads and higher transport costs (materials and equipment);

3)Necessary credit indebtedness, growth of interest on other people's funds, complexity of applying for EU funds, slow return on investments, difficult servicing of loans; 4)Shortage, seasonal employment in neighboring countries and emigration of locally educated and experienced staff; 5)The predominant tourist population and the fragmentation of the offer in the tourist zone undermines the impression of exclusivity, non-recognition of the added value of the offer by the targeted tourist segments;

6)Modest promotion and poor visibility of the tourist zone in the global tourist market results in seasonality of visits; 7)Limited accommodation capacity, risk of financially unfavorable categorization of accommodation by the relevant Ministry-higher costs of utility equipment, space restrictions for the installation of solar panels; 8)Reducing the attractiveness of the tourist zone due to uncontrolled tourist construction, endangering the landscape and the sea.
Based on the TOWS analysis, the choice of strategy of strengths and possibilities is suggested because the accommodation concept of the specialized tourist offer is adapted to post covid 19 time. The characteristics of the microlocation are a precondition for the development of additional and expanded contents of the specialized tourist offer that would be primarily offered on emitting markets with bad microclimatic conditions. Road and air corridors are a prerequisite for yearround visits and good occupancy, given that this is a smaller accommodation capacity that will be offered to businesses in a targeted manner for the organized stay of their employees in business training and team building. The available recreational zone in the environment of the receptive subject and the possibility of obtaining a concession are prerequisites for offering a variety of additional and expanded contents. The existing good image of the investor in the environment, property of the land, established cooperation with supply entities and resource concessionaires in the wider environment are also a prerequisite for the development of additional and supplementary contents. The existing contacts and partners in several emitting tourist markets will simplify communication and promotion of a specialized tourist product given the growing interest in tourist facilities based on sustainable environmental standards, eco gastronomic offer, and implementation of digital user platforms in the offer. The cost-effectiveness of the planned technical and technological solutions in the project with the available insourcing and outsourcing resources also lead to the selection of a strategy of strengths and opportunities in the implementation of the project. 
Table 3.

PESTEC analysis.

\begin{tabular}{|c|c|c|c|c|}
\hline $\begin{array}{l}\text { Market environment } \\
\text { segment }\end{array}$ & Features & $\begin{array}{l}\text { Strength of } \\
\text { influence }\end{array}$ & Significance & Overall rating \\
\hline \multirow[t]{3}{*}{ Political } & $\begin{array}{l}\text { State subsidies for the application } \\
\text { of environmental solutions } \\
\text { (renewable energy sources and } \\
\text { waste disposal) and EU funds for } \\
\text { eco-sustainable tourism offer. }\end{array}$ & +3 & 7 & +21 \\
\hline & $\begin{array}{l}\text { Current political instability at the } \\
\text { national level and constraints due } \\
\text { to epidemiological circumstances. }\end{array}$ & -3 & 5 & -15 \\
\hline & Subtotal & & & +6 \\
\hline \multirow[t]{3}{*}{ Economic } & Profit margin & +4 & 10 & +40 \\
\hline & Return of investment & -2 & 8 & -16 \\
\hline & Subtotal & & & +24 \\
\hline \multirow[t]{3}{*}{ Social } & Post covid tourist behavior & +3 & 6 & +18 \\
\hline & $\begin{array}{l}\text { Perception of tourist zone } \\
\text { exclusivity }\end{array}$ & -2 & 7 & -14 \\
\hline & Subtotal & & & +4 \\
\hline \multirow[t]{3}{*}{ Technological } & Technological smart equipment & +3 & 8 & +24 \\
\hline & $\begin{array}{l}\text { Costs, purchase and maintenance } \\
\text { of smart technological equipment }\end{array}$ & -1 & 7 & -7 \\
\hline & Subtotal & & & +17 \\
\hline \multirow[t]{3}{*}{ Geo - climatic } & Microclimatic conditions & +5 & 10 & +50 \\
\hline & Climate changes & -2 & 5 & -10 \\
\hline & Subtotal & & & +40 \\
\hline \multirow[t]{3}{*}{ Cultural } & Resources / attractions & +3 & 6 & +18 \\
\hline & Global trends & -3 & 8 & -24 \\
\hline & Subtotal & & & -6 \\
\hline Sum & & & & +85 \\
\hline
\end{tabular}

The findings of the Pestec analysis should be observed, taking into account the limitation of the selection of two (key / strategic) aspects for each analyzed feature of the environmental segments. In order to ensure the relevance of the assessment despite this fact, the application of this method has selected opposite characteristics, which have then been evaluated by the strength of influence and significance in order to know the quantitative positive and negative assessment of each of the five key environmental characteristics. Quantification has been performed using a multidisciplinary focus group. The final quantitative assessment $(+85)$ argues the perspective of the assumed specialized tourist offer, but also warns of the need to adhere to the defined standards, both in the technical implementation of the project and its contents. The specialized tourist offer of the basic content, taking into account all aspects of the environment, has no economic perspective without additional and expanded contents. The additional and expanded content should be clearly visible in the offer, which means their implementation in the strategy and brand of a specialized tourism product. 
Table 4.

MOF analysis.

\section{Marketing}

Strengths and opportunities

- Originality and eco friendly offer;

- Experience and available staff for e-marketing especially through social networks, originality of the offer - potential for international publicity;

- Possibility to expand the content;

- Existing business communication with certain emitting tourist markets;

- Positioning the offer in the niche of small businesses-for educational and team building organized stays of employees.
Weaknesses and limitations

- Negative image of receptive country given the number of sick and dead from covid-19 per 100,000 inhabitants;

- Negative perception of the country in terms of transport accessibility, legal security (not a member of the European union);

- The receptive subject and his brand are completely unknown in the global tourist market.

\begin{tabular}{|c|c|}
\hline \multicolumn{2}{|c|}{ Operations } \\
\hline Strengths and opportunities & Weaknesses and limitations \\
\hline $\begin{array}{l}\text { - Project management experience and business competencies; } \\
\text { - Assumed organizational and logistical business model; } \\
\text { - Potential for continuous development of additional and } \\
\text { supplementary content of the offer. }\end{array}$ & $\begin{array}{l}\text { - Distance of the location from the highway crossroads-distance } \\
\text { from the large emitting tourist markets of Europe; } \\
\text { - Most airlines to the nearest airports (Tivat, Dubrovnik) do not } \\
\text { have a year-round continuity. }\end{array}$ \\
\hline \multicolumn{2}{|c|}{ Finance } \\
\hline Strengths and opportunities & Weaknesses and limitations \\
\hline $\begin{array}{l}\text { - Good current liquidity and previous business of investors; } \\
\text { - Good creditworthiness and established cooperation with } \\
\text { banks; } \\
\text { - Available and vacant real estate for mortgage loans. }\end{array}$ & $\begin{array}{l}\text { - Insufficient own funds for self-financing of the project; } \\
\text { - Adverse loans; } \\
\text { - Business disruptions during the covid } 19 \text { pandemic; } \\
\text { - Expected global recession after the end of the covid pandemic. }\end{array}$ \\
\hline
\end{tabular}

The findings of the MoF analysis have confirmed the possibility of technical realization of the project of a specialized tourist product with the share of the necessary additional financial indebtedness. The consequences of the covid 19 pandemic will have an impact on the dynamics of the return on the investment, so the cost of bank borrowing should be taken into account. The currently reduced volume of airlines to the two airports in the area will be normalized as the epidemiological situation calms down. In the meantime (due to lower travel intensity) the propulsion of road corridors will be increased. This indicates the balance of transport logistics in the current situation and in the future. The future primary orientation towards airlines imposes a need for organization of own transfers to airports. The findings of previous project analyses have indicated the same. The current negative image of the receptive country, given the ratio of the number of sick and dead per 100,000 inhabitants of the covid 19 pandemic, is expected to be removed by the normalization of the health situation. A change in perceptions of the country's transport accessibility and legal security is also to be expected, as the local population is oriented towards membership in the European Union. But the fact that the receptive subject and his brand are completely unknown to the global tourism market imposes a need for aggressive promotion in which additional and expanded content due to originality and environmental standards represent a usable perspective, provided they are fully implemented in marketing strategy and brand of a specialized tourism product. 
Table 5.

RECOIL analysis.

\begin{tabular}{|c|c|c|c|c|}
\hline R- resources & E - experience & CO - control & I - ideas & L - leadership \\
\hline $\begin{array}{l}\text { - Equity reserves and } \\
\text { experience in financial } \\
\text { planning; } \\
\text { - Experienced } \\
\text { management; } \\
\text { - Good external image } \\
\text { of the subject; } \\
\text { - Own construction and } \\
\text { assembly capacities, } \\
\text { own land on a location } \\
\text { desirable for the } \\
\text { planned content; } \\
\text { - Marketing } \\
\text { competencies for } \\
\text { development and brand } \\
\text { management. }\end{array}$ & $\begin{array}{l}\text { - Previous experience in } \\
\text { tourism business; } \\
\text { - Existing offer of tourist } \\
\text { accommodation of the } \\
\text { company; } \\
\text { - Adapting to market } \\
\text { changes; } \\
\text { - Cooperation with } \\
\text { tourism entities in the } \\
\text { country and abroad; } \\
\text { - Cooperation with } \\
\text { business entities in the } \\
\text { environment. }\end{array}$ & $\begin{array}{l}\text { - Marketing planning; } \\
\text { - Business forecasting in } \\
\text { projects; } \\
\text { - Proactive } \\
\text { management of new } \\
\text { projects; } \\
\text { - Monitoring the } \\
\text { experiences of } \\
\text { foreign and domestic } \\
\text { competition; } \\
\text { - Use of modern } \\
\text { technologies in } \\
\text { monitoring and } \\
\text { analysis of markets and } \\
\text { business. }\end{array}$ & $\begin{array}{l}\text { - Innovative offer; } \\
\text { - Adapting the content } \\
\text { to the needs of tourist } \\
\text { groups; } \\
\text { - Smart-eco concept of } \\
\text { supply; } \\
\text { - Authenticity of the } \\
\text { offer and strengthening } \\
\text { the perception of the } \\
\text { value of the tourist } \\
\text { offer; } \\
\text { - Development and } \\
\text { brand management of } \\
\text { the receptive subject. }\end{array}$ & $\begin{array}{l}\text { - Authority and } \\
\text { creditworthiness of } \\
\text { project owners and } \\
\text { managers in the } \\
\text { receptive market and } \\
\text { with foreign partners; } \\
\text { - A family business } \\
\text { with clearly defined } \\
\text { responsibilities; } \\
\text { - Commitment to } \\
\text { business continuity } \\
\text { optimization; } \\
\text { - Commitment of all } \\
\text { family members to the } \\
\text { project. }\end{array}$ \\
\hline
\end{tabular}

Finally, the findings of the Recoil analysis argue the justification of the project. Experience in entrepreneurship, tourism, and construction with available resources, primary land property and sources of own and bank capital, are a prerequisite for the implementation of the project within the planned deadlines. Marketing competencies for brand development and managementarea prerequisiteforan appropriateimplementation of additional and expanded contents of the offer in the strategy and brand image of a specialized tourism product. A good image of the investor in the business environment is a prerequisite for the development of cooperation with business entities, which in turn is a prerequisite for the development of additional and expanded contents. The existing cooperation with tourism entities in the country and abroad is useful in strengthening the visibility of the future brand. The practice of monitoring the situation in the receptive and some emitting markets enables the prediction of trends and adaptation to future market changes. Orientation of the basic content of the specialized tourist offer towards modern technologies will contribute to its additional attractiveness, but also to the monitoring and analysis of business and monitoring of the situation on the target tourist markets. The implementation of modern technologies in the offer enables an easier adaptation of various contents to the needs of tourist groups, and the smart eco concept of the offer is also a current tourist trend. All this contributes towards the authenticity of the specialized tourist product and the impression of added value. The basic, additional, and expanded contents of the specialized tourist offer designed in this way inspires the implementation of various brand management activities. Finally, the authority and business creditworthiness of the project holder company are a prerequisite for establishing cooperation with partners who can contribute to the implementation of the project and the inclusion of new entities in the supply chain. The fact that the project will be realized by a family company with experience in tourism business and the commitment of all members of the extended family to the projects are a prerequisite for the rational and responsible realization of the set mission and vision of the project.

\section{CRITICAL REVIEW OF RESEARCH FINDINGS}

Although it is difficult to predict the end of the covid-19 pandemic, the population of countries where the disease is under control are re-engaging in tourist migration. Innovative tourist facilities in destinations that are perceived as safe for health are selected. The pleasant micro-climate is also associated with the desirability of the destination. Finally, the diversity of tourist facilities is another feature that contributes to the competitiveness of the offer. The findings of the research have proved the importance of the originality of the additional and expanded contents of the offer for its attractiveness. Additional and expanded content simplifies maintaining the competitiveness of the tourist offer, also representing a prerequisite for attracting a larger number of tourist segments and a growth of annual tourist visits. The availability of the location of the receptive subject to large emitting tourist markets and good transport connections with attractive and favourable microclimatic conditions also positively contribute towards the growth of tourist visits. The 
diversity of available resources is a prerequisite for a variety of basic, additional,s and expanded content of the tourist offer. The implementation of additional and expanded contents in the marketing strategy and brand of a specialized tourist product contributes to its global visibility and a more intensive response of tourists. Assumed smart technologies, in addition to positive repercussions on future business costs, will also contribute to the attractiveness of a specialized tourism product. The concept of tourist offer and available land are a limit to the number of accommodation units. But this should be used in the context of the exclusivity of the offer. The fragmentation of the tourist offer in the environment encourages the valorization of all available resources, and the development of additional and expanded contents. The modest national tourism promotion of the receptive country results in poorer global visibility. This fact suggests a more aggressive strategy and intensive brand positioning activities of the specialized tourist offer. The originality of the strategy and the attractiveness of the brand are further enhanced by the breadth and diversity of the contents of the offer. The additional and expanded contents are imposed as important components of marketing strategy and brand. The post covid time imposes a different approach to creating and managing a specialized tourism product, marketing strategy and brand. Positioning in a niche of safe, ecological and active content in landscapeattractive locations with various additional and expanded contents are prerequisites for attracting a larger number of tourist segments in the post-covid time. The possibility of obtaining state subsidies and grants from earmarked funds of the European Union reduces the financial risks of commercialization of the project. The originality and attractiveness of the contents of the tourist offer are a precondition for a higher profit margin, given the expected slower return on investment during the first years of commercialization of the project. The adaptation of the specialized tourist product to post covid time is evident, but one should be aware of the existing impression of lower exclusivity of the tourist zone in which the project is being implemented. The pursuit of the exclusivity of the offer and the receptive subject implies more intensive marketing, especially when choosing a marketing strategy, and selective brand management activities. As much as technological smart solutions and such equipment contribute to the attractiveness of the specialized tourist offer, the cost and complexity of maintaining it with possible procurement problems could have negative repercussions during the first years of business. Favourable microclimatic conditions in the geographical commercialization zone of the project diminish the impression of global climate change. The variety of resources can be valorized through the additional and expanded contents of a specialized tourism product and is expected to have positive repercussions on the recognizability of the offer on the global market. Taking into account all the findings of the conducted research, the choice of a strategy that will use the strengths and possibilities of the project becomes imperative. The commitment to this strategy, in addition to the TOWS analysis, is also imposed by the findings of the MOF analysis. The currently negative image of the receptive country should be borne in mind, given the statistics of patients and deaths from the covid-19 pandemic, as well as the fact that Montenegro is not yet a member of the European Union. The original concept of a specialized tourism product, the modest global visibility of the receptive country, destination and receptive tourism entities lead to aggressive marketing strategies and complex brand management activities, which the authors will address in more detail in a new research. Weakness due to the distance of the receptive subject's location from the highway hub will diminish the renewal of numerous airlines to surrounding airports in the post covid time. Entrepreneurial experience, positive business, ownership of the land on which the receptive subject is located and the possibility of using their own real estate as a collateral for a mortgage loan, are the arguments that encourage the realization of the project. All the findings from the research suggest the inclusion of additional and expanded contents of a specialized tourism product in the marketing strategy and brand.

The limitation of the research is the smaller number of analyzed features in the PESTEC analysis. In order to offset it, reducing it to an acceptable level, conflicting characteristics have been selected for evaluation. The attractiveness of certain features of a specialized tourist product could not be tested on tourists since it is not yet possible to receive tourists. Therefore, market testing has been conducted through focus groups in which representatives of travel agencies and tourist offices in the Republic of Croatia and Montenegro have participated.

Based on the research findings, it can be concluded that the concept of mini smart eco village in Zelenika Bay near Herceg Novi on the Montenegrin coast will attract the target tourist population due to wide possibilities of additional and expanded contents - organized groups of company employees who would hold trainings and team building programmes. Available resources and local traditions provide a wide range of attractive educational, gastronomic, sports, spiritual, health, entertainment, and other contents with the receptive subject. The envisaged user smart solutions will contribute to the originality and efficiency of various programmes and the attractiveness of a specialized tourism product. The use of energy from renewable sources, the implementation of energy efficiency standards and eco-certification are prerequisites for securing part of the funds for the implementation of the project from earmarked national and foreign funds. The specific requirements of the post-covid times, changes in the behaviour of tourists when choosing a destination and specialized tourist products offered in tourist areas that do not yet have an exclusive image or good global visibility, undoubtedly necessitate aggressive marketing activities. The additional and expanded contents in 
the conditions of available diverse resources is imposed as a marketing full-fledged component of the competitiveness of a specialized tourist product. They should be implemented in the same way in the marketing strategy and brand. This knowledge is also the answer to a fundamental research question in the context of testing the presented model of development of a specialized tourist product.

\section{CONCLUSION}

The consequences of the covid-19 pandemic on the global tourism economy will be evident, not only in the intensity of international arrivals and overnight stays, but also in the choice of destinations and tourist facilities. Safety and purity, and the isolation of the receptive subject are of primary importance in the post covid time. Tourists will travel more often by car, choosing closer destinations, especially the more isolated ones. Due to the tendency to strengthen the body's immunity, tourists will opt more for areas with preserved landscapes and receptive entities in which dispersed accommodation is possible. The tourism economy will recover, but the dynamics of recovery for individual countries, tourist zones and receptive entities will be different. Tourists' awareness of the importance of preserving the environment, striving to get closer to the local population and an increasing interest in the indigenous products suggest that the additional and expanded contents of the specialized tourist offer is more intensively emphasized in the marketing strategy and brand. The same is indicated by changes in social values in the global tourism market. Diversification of specialized tourism products at the level of the national receptive country will contribute towards improving its competitiveness. The wider content of specialized tourist products enables a more moderate consumption of non-renewable resources. Modern technological solutions contribute to the impression of originality and quality of a specialized tourist product. They also contribute to the simplicity of hospitality operations. The digital transformation is incomparable in speed, scope, and impact on receptive subjects with previous experiences. The role of modern technological solutions in specialized tourism products also depends on a defined vision and mission. Nevertheless, the contribution to the automation of the service process, productivity,u and efficiency of the catering service is evident. Artificial intelligence will also play an increasing role in this. Based on the information on the behavior of tourists, it will be possible to predict the business of the receptive subject. Modern technological solutions will contribute towards a lowering the energy and other operating costs of the receptive subject. The focus of marketing activities from the basic contents of a specialized tourism product should be expanded to additional and expanded contents. The Covid-19 pandemic draws tourists' attention to smaller receptive subjects in a preserved natural environment with accompanying outdoor facilities. The importance of the impression of the quality of a specialized tourist product is growing. That impression is easier to maintain on an expanded content. Furthermore, this indicates the need for a more intensive implementation of additional and expanded contents in the marketing strategy and brand of a specialized tourism product. The overall, expanded content of the specialized tourist offer is a precondition for its year-round attractiveness. It should be borne in mind that the end of the covid-19 pandemic will be followed by a recession. Then the maintenance of the intensity of the tourist visit will significantly depend on the adjustment of the offer to the targeted tourist segments. The competitiveness of a specialized tourist product is, in this sense, significantly enhanced by the additional and expanded contents. Tourist zones in the immediate vicinity of the European Union's emitting market have the prospect of increasing visits. Specialized forms of tourist offer, with the creative additional and expanded contents in the preserved landscape with pleasant microclimatic conditions, have a perspective of growth and development. Competitiveness can be maintained by diversification, constant quality improvement, and content expansion. Therefore the implementation of additional and expanded contents of each specialized tourism product in the marketing strategy and brand in the post-covid time is implied. This will also contribute towards strengthening the global visibility of the brand of the specialized tourist product and the receptive subject. The broader impression of the overall contents of the specialized tourist product also enables the opening of new emitting tourist markets and the attraction of new segments of tourists.

\section{REFERENCES}

Baggio, R., 2019. The science of complexity in the tourism domain: a perspective article. Tourism Review, 75(1), pp.16-19. Available at:

http://dx.doi.org/10.1108/tr-04-2019-0115.

Boes, K., Buhalis, D. \& Inversini, A., 2016. Smart tourism destinations: ecosystems for tourism destination competitiveness U. Gretzel, Lina Zhong and Chulmo Koo, ed. International Journal of Tourism Cities, 2(2), pp.108-124. Available at: http://dx.doi.org/10.1108/ijtc-12-2015-0032.

Buhalis, D. \& Sinarta, Y., 2019. Real-time co-creation and nowness service: lessons from tourism and hospitality. Journal of Travel \& Tourism Marketing, 36(5), pp.563582. Available at:

http://dx.doi.org/10.1080/10548408.2019.1592059.

Buhalis, D. et al., 2019. Technological disruptions in services: lessons from tourism and hospitality. Journal of Service Management, 30(4), pp.484-506. Available at: http://dx.doi.org/10.1108/josm-12-2018-0398.

Buhalis, D. \& Foerste, M., 2015. SoCoMo marketing for travel and tourism: Empowering co-creation of value. Journal of Destination Marketing \& Management, 4(3), pp.151-161. Available at:

http://dx.doi.org/10.1016/j.jdmm.2015.04.001.

Cooper, C., 2021. Essentials of tourism, SAGE Publications Limited. 
Prayag, G., 2020. Time for Reset? Covid-19 and Tourism Resilience. Tourism Review International, 24(2), pp.179-184. Available at: http://dx.doi.org/10.3727/154427220x15926147793595.

Gössling, S., Scott, D. \& Hall, C.M., 2020. Pandemics, tourism and global change: a rapid assessment of COVID-19. Journal of Sustainable Tourism, 29(1), pp.1-20. Available at:

http://dx.doi.org/10.1080/09669582.2020.1758708.

Hall, C.M., Scott, D. \& Gössling, S., 2020. Pandemics, transformations and tourism: be careful what you wish for. Tourism Geographies, 22(3), pp.577-598. Available at: http://dx.doi.org/10.1080/14616688.2020.1759131

Jafari, J., Xiao, H., 2021. Encyclopedia of Tourism, Springer.

Jakšič-Stojanović, A. \& Šerić, N., 2020. Valorization of Montenegrin Lighthouses as Destination Icons Through Different Forms of Multimedia Arts. Lecture Notes in Networks and Systems, pp.939-946. Available at:

http://dx.doi.org/10.1007/978-3-030-46817-0_106.

Jakšić Stojanović, A., Šerić, N., (2019), Sports and Health as Corner Stones of Tourism Development - Case Study of Montenegro, u Sports Science and Human Health - Different Approaches, Intech Open Limited (www.intechopen.com/aboutintechopen), London.

Jaksic-Stojanovic, A. et al., 2019a. Montenegro as High-Quality Sports Tourism Destination- Trends and Perspectives. Sport Mont, 17(1), pp.93-95. Available at: http://dx.doi.org/10.26773/smj.190218.

Jakšić Stojanović, A., Janković, M. \& Šerić, N., 2019b. Montenegro as a high-quality health tourism destination: Trends and Perspectives, African Journal of Hospitality, Tourism and Leisure Volume 8 (3), pp. 1 - 9

Jakšić Stojanović, A., Janković, M., Šerić, N., Vukilić, B., Ibrahimi, A., 2019c. Branding of protected areas and National Parks: A case study of Montenegro, African Journal of Hospitality, Tourism and Leisure Volume 8 (2), pp. 1 - 9.

Jakšić Stojanović, A., Šerić, N. \& Perišić, M., 2019. Marketing management of the lighthouse heritage in the function of strengthening the national identity on the global tourism market: Stone Lights (Croatia) and the art of the lighthouses (Montenegro), Proceedings of the Faculty of Economics in East Sarajevo n. 19, pp. 83 - 98. Available at: http://dx.doi.org/10.7251/zrefis1919083j.

Jakšić Stojanović, A. \& Šerić, N., 2018a. The Montenegrin Lighhouses as Destination Icons, University Mediterranean, Podgorica, Montenegro.

Luković, T. \&Šerić, N., 2009. Strategic development and changes in legislation regulating yachting in Croatia, Journal of Maritime Studies, 23(2), pp. 357-374.

Melović, B. et al., 2018. Mogućnosti i ograničenja brendiranja Kotora kao crnogorske turističke destinacije, Proceedings of the VII Scientific conference Sustainable tourism and institutional environment, Jahorina, pp. 187 - 194.

Nunkoo, R., Seetanah, B. \& Agrawal, S., 2019. Guest editorial. Tourism Review, 74(2), pp.129-137. Available at:

http://dx.doi.org/10.1108/tr-04-2019-209.

Prideaux, B., Thompson, M. \& Pabel, A., 2020. Lessons from COVID-19 can prepare global tourism for the economic transformation needed to combat climate change. Tourism Geographies, 22(3), pp.667-678. Available at: http://dx.doi.org/10.1080/14616688.2020.1762117.

Prorok, V., Šerić, N. \& Peronja, I., 2019. Analysis of Overall and Pure Technical Efficiency of Tourism in Europe. Transactions on Maritime Science, 8(2), pp.219-229.
Available at:

http://dx.doi.org/10.7225/toms.v08.n02.007.

Richards, G., 2019. Culture and tourism: natural partners or reluctant bedfellows? A perspective paper. Tourism Review, 75(1), pp.232-234. Available at: http://dx.doi.org/10.1108/tr-04-2019-0139.

Ruhanen, L., Moyle, C. \& Moyle, B., 2019. New directions in sustainable tourism research. Tourism Review, 74(2), pp.138-149. Available at:

http://dx.doi.org/10.1108/tr-12-2017-0196.

Šerić, N., Jakšić Stojanović, A. \& Bagarić, L., 2021. Model kreiranja specijaliziranog turističkog proizvoda za post covid vrijeme, Proceedings of the $X$ Scientific Conference Jahorina business forum 2021: South east Europe in the vortex of the 2020 crisis, disruptive innovation, policies and measures for sustainable economic growthx, Jahorina, Istočno Sarajevo, pp. 85 - 97.

Šerić, N., Marušić, F. \& Peronja, I., 2020a. Upravljanje razvojem specijaliziranog turističkog proizvoda, Redak Split.

Šerić, N., Mihanović, A. \& Tolj, A., 2020. Model for the Development of a Specialized Dark Tourist Product. Transactions on Maritime Science, 9(2). Available at: http://dx.doi.org/10.7225/toms.v09.n02.014.

Šerić, N. \& Marušić, F., 2019. Tourism Promotion of Destination for Swedish Emissive Market. Advances in Economics and Business, 7(1), pp.1-8. Available at: http://dx.doi.org/10.13189/aeb.2019.070101.

Šerić, N. \& Batalić, M., 2018. Marketinško upravljanje informacijama u funkciji jačanja privlačnosti turističke destinacije, Podstranska revija XVII br. 36, Ogranak Matice Hrvatske u Podstrani, pp. 12-15.

Šerić, N., Jerković, M. \& Bučić, K., 2017. Mogućnosti kreiranja turističke marke zaobalne destinacije Svilaja Moseć, Zbornik radova Župa Ogorje - Putovima života i vjere između Svilaje i Moseća, pp. 467 - 486.

Šerić, N., Ljubica, J., Jerković, M., 2015. Evaluation of the tourist resort strategic management model in the eastern Adriatic littoral, Proceedings of the 11. International Conference Challenge of Europe, Faculty of economics, Split, pp. 273 -290 .

Šerić, N. \& Luković, T., 2007. Primjena BPD (Build Primary Demand) modela razvoja tržišne strategije tranzicijskih tržišta, Ekonomska misao i praksa, 1, pp. 99 - 110.

Šerić, N., Ikač, M. \& Vidović, Z., 2002. Disposal of waste water in ecologically sensitive environment of lighthouse, Conference proceedings 44th International Symposium ELMAR, Zadar, pp. 135-139

UN, 2020. Ending Poverty. Available at: https://www.un.org/en/sections/i.

UNWTO, 2020. World Tourism Barometer May 2020, Special focus on the impact of Covid-19, Madrid. Available at: https://webunwto.s3.eu-west-1.amazonaws.com/ s3fs-public/2020-05/Barometer\%20-\%20May\%202020\%20-\%20Short.pdf.

Wen, J. et al., 2020. COVID-19: potential effects on Chinese citizens' lifestyle and travel. Tourism Review, 76(1), pp.74-87. Available at: http://dx.doi.org/10.1108/tr-03-2020-0110.

WTTC, 2020. To Recovery / Beyond: The Future of Travel \& Tourism in the Wake of Covid-19, WTTC - Oliver Wyman, September 2020. Available at: https://wttc.org/ Research/To-Recovery-Beyond/moduleld/1707/itemld/18.

Zhang, $\mathrm{H}$. et al., 2021. Forecasting tourism recovery amid COVID-19. Annals of Tourism Research, 87, p.103149. Available at: http://dx.doi.org/10.1016/j.annals.2021.103149. 